\title{
Pandemi dan Krisis Multidimensi: Studi Kasus Permasalahan Gender di Tengah Pandemi COVID-19

\author{
Supartinab ${ }^{1}$ dan Abmad Anwar ${ }^{2}$ \\ Universitas Sains Al-Qur'an
}

\begin{abstract}
This paper emphasizes that the Covid-19 pandemic is not just a health issue. It has caused a global economic crisis and most importantly a negative impact on gender inequality. The data was collected mainly from the UN Women and projected using content-analysis methods. Using a gender perspective, this study explains that the gender issues as a result of this crisis arise from economic activities that are not distributed fairly. In turn, this has spread to social lives of men and women with significantly more exposed women which are enforced in almost all countries. Job losses and the quality of life for both men and women have decreased. They are forced to make ends meet with increasingly limited resources. This can hamper the ongoing efforts on women's rights fulfilment and gender equality.
\end{abstract}

Keywords: covid-19, economic crisis, gender issue

\section{PENDAHULUAN}

Sejak awal tahun 2020, kelesuan sosial dan ekonomi akibat pandemi Covid-19 (Coronavirus Disease of 2019) terus mendominasi kehidupan jutaan orang. Hal ini tidak hanya terjadi di negara tertentu, tetapi juga di hampir semua negara yang pada awalnya tampak dapat mengatasi penyebaran Covid-19. Upaya pencegahan virus tersebut kebanyakan dilakukan dengan membatasi mobilitas masyarakat (lockdown).

Akibatnya, hal ini justru menyebabkan roda perekonomian terhambat dan bahkan mengurangi prospek pemulihan ekonomi. Bahkan pandemi tersebut menyebabkan krisis ekonomi global. Krisis yang parah ini telah menyebabkan resesi di beberapa negara dan depresi di beberapa negara lain. Krisis ini menjadi krisis ekonomi global terburuk sejak the Great Depression (Gaetano 2020). Krisis akibat Covid-19 dimulai karena dampak ekonomi dari pandemi yang terus berlangsung (The Guardian 2020). Pertanda besar pertama dari resesi ini adalah jatuhnya pasar saham tahun 2020, yang dimulai pada akhir Februari dan berlangsung hingga Maret. Pada September 2020, disaat kebanyakan negara berkembang berada dalam resesi, beberapa negara ekonomi maju telah jatuh ke dalam depresi ekonomi (IMF 2020).

Selain itu, tingkat pengangguran terbuka yang tinggi, ketidakamanan pangan, turunnya investasi, dan meningkatnya ketegangan sosial telah menjadi hal yang tidak dapat dihindari. Ini adalah tren mengkhawatirkan yang menunjukkan kemunduran signifikan dalam 
pemenuhan kebutuhan manusia di seluruh dunia. Dengan kata lain, Covid-19 telah menimbulkan konsekuensi jangka panjang yang merugikan baik secara sosial maupun ekonomi. Bukti yang muncul menunjukkan bahwa dalam episode krisis kali ini, sama seperti dalam krisis finansial global 2008 sebelumnya, efek buruk ekonomi juga dirasakan oleh kelompok sosial yang kurang kuat, terutama mereka yang berpenghasilan menengah dan rendah, perempuan dalam rumah tangga, serta etnis dan ras minoritas.

Paper ini berfokus pada dinamika gender dalam respons krisis, tanpa mengabaikan aspek distribusi lainnya yang bersinggungan dengan ketidaksetaraan gender dan melemahkan keadilan sosial secara lebih luas. Untuk itu, tulisan ini disusun sebagai berikut: bagian kedua mengulas beberapa literatur yang berkaitan dengan tema krisis akibat Covid-19 dan gender. Bagian ini juga akan menekankan apa pentingnya memahami krisis melalui perspektif gender. Bagian ketiga memberikan analisis menyeluruh tentang penyebab krisis global akibat Covid19. Bagian keempat membahas dampak krisis tersebut dari perspektif gender untuk mengeksplorasi bagaimana perempuan dan laki-laki telah terkena dampak secara berbeda. Selanjutnya sebelum kesimpulan, paper ini mendiskusikan bagaimana pandemi ini begitu berdampak pada perempuan.

Paper ini disusun dengan menggunakan data yang bersumber dari UN Women terutama data yang dirisil dalam satu tahun terakhir (2020-2021). Data tersebut diakses dengan cara library-research. Sementara itu, metode content-analysis digunakan untuk menganalis aspek-aspek terkait isu gender dan Covid-19. Dalam hal ini, metode kualitatif digunakan untuk menganalisis 'kualitas' data yang penting untuk disajikan.

\section{TINJAUAN LITERATUR/KERANGKA ANALITIS}

Bagian ini membahas bagaimana krisis ekonomi sebelumnya memiliki dampak yang berbeda terhadap pekerja perempuan dan laki-laki. Doepke dan Tertilt (2016) menjelaskan bahwa pada periode 1989-2014, laki-laki menyumbang lebih dari tiga perempat dari keseluruhan fluktuasi siklus pekerjaan. Sementara itu, perempuan menyumbang kurang dari seperempat. Temuan tersebut menerangkan bahwa jam kerja pria jauh lebih tidak stabil dibandingkan jam kerja perempuan. Temuan serupa mengatakan bahwa pekerjaan laki-laki rata-rata lebih terkonsentrasi di sektor-sektor dengan eksposur siklus yang tinggi, sedangkan perempuan sangat terwakili di sektor-sektor dengan pekerjaan yang relatif stabil (Coskun dan Dalgic 2020). Kedua literatur tersebut pada intinya menyimpulkan argument yang hampir sama: kemerosotan di masa lalu telah memengaruhi pekerjaan pria jauh lebih parah daripada perempuan. 
Bagaimana dengan krisis akibat Covid-19? Beberapa studi tentang gender dan Covid19 lebih banyak terfokus pada permasalahan Kesehatan dan psikologi. Tingkat keparahan dan mortalitas akibat infeksi Covid-19 pada pria adalah dua kali lebih tinggi daripada perempuan (Jin dkk. 2020). Tetapi virus juga telah menimbulkan dampak yang tidak proporsional pada kesehatan psikologis dan fisik perempuan sehari-hari. Dibandingkan dengan pria, perempuan melaporkan stres dan kecemasan yang lebih besar selama tahap awal lockdown di Spanyol dan Hungaria (Ausín dkk. 2021), serta tekanan psikologis yang lebih besar setelah lockdown awal di Israel (Horesh, Kapel Lev-Ari, dan Hasson-Ohayon 2020). Akibat pandemi ini, banyak rumah sakit lebih dikhususkan untuk layanan pasien Covid-19 daripada pasien umum. Hal ini meningkatkan angka kematian ibu di negara-negara yang biasanya banyak praktek aborsi (Cousins 2020). Efek negatif diperburuk oleh mereka yang berasal dari kelompok marjinal seperti perempuan etnis minoritas dan perempuan dalam kemiskinan, karena kelompok-kelompok ini berisiko tinggi mengalami marjinalisasi layanan kesehatan (Hafi dan Uvais 2020).

Beberapa studi meneliti hubungan krisis Covid-19 dengan pekerjaan dan tanggungjawab dalam rumah tangga. Sebuah studi mengatakan bahwa disaat tanggung jawab rumah tangga dan pengasuhan anak meningkat bagi banyak orang selama pandemi, ketidaksetaraan gender justru paling terlihat di kalangan / keluarga yang memiliki anak (Carlson, Petts, dan Pepin 2020). Sementara kalangan istri melaporkan peningkatan yang lebih besar dalam pekerjaan rumah tangga dan perawatan daripada suami, mereka juga melaporkan penurunan 5\% dalam jam kerja, sementara jam kerja suami sebagian besar tetap stabil (Collins dkk. 2021). Selain itu, pihak istri lebih cenderung bertanggung jawab penuh untuk mendidik anakanak mereka (Carlson dkk. 2020).

Lalu apa pentingnya perspektif gender dalam memaknai krisis ekonomi akibat Covid19? Setidaknya ada tiga keuntungan dari perspektif gender dalam memahami krisis. Pertama, perspektif tersebut membantu memaknai dinamika distribusi dan ketidaksetaraan, misalnya dalam pekerjaan dan pendapatan, seperti yang dijelaskan di bawah ini berimplikasi erat sebagai sebab dan akibat dari krisis.

Kedua, perspektif gender tentang ekonomi memberikan perspektif sosiologis terhadap aktifitas informal. Misalnya adalah aktivitas dan hubungan sosial dalam pemenuhan kebutuhan dasar sehari-hari dalam rumah tangga. Bukti studi kasus dari krisis 1970-an menunjukkan bahwa dalam konteks krisis dan penghematan pasca krisis, tuntutan pekerjaan secara tidak proporsional oleh perempuan cenderung meningkat (Knowles, Pernia, dan 
Racelis 1999; Rocha 1988): hilangnya pendapatan dapat memaksa suatu keluarga untuk mengubah pola konsumsi dengan mengganti barang dan jasa yang dibeli dengan barang pengganti buatan sendiri. Memang benar bahwa kebanyakan perempuan atau ibu rumah tangga memiliki waktu yang lebih fleksibel. Mereka mampu menutupi kekurangan dalam pendapatan rumah tangga dengan melakukan aktifitas yang dapat menghasilkan penghasilan tambahan. Namun, tindakan keluarga seperti itu dapat berimplikasi buruk pada kesejahteraan perempuan sendiri, serta dampak langsung yang mungkin ditimbulkannya terhadap kesejahteraan anak-anak dan anggota keluarga yang lain.

Ketiga, perspektif gender juga berguna untuk menjelaskan pergeseran norma sosial yang lebih luas di saat krisis. Misalnya, ketika di tingkat keluarga laki-laki yang kehilangan pekerjaan terpaksa melakukan 'pekerjaan perempuan' dan sebaliknya, perempuan mungkin akan terpaksa melakukan 'pekerjaan pria' untuk membantu perekonomian keluarga. Dalam kasus krisis global sebelumnya, banyak perempuan yang harus menjadi pekerja migran (Reddock dkk. 2009). Identitas maskulin tradisional tergeser ketika laki-laki kehilangan peran 'pencari nafkah' mereka. Namun selain itu, ketidakharonisan keluarga akibat ekonomi yang sulit juga dapat memicu tindak kekerasan. Sebagaimana dalam krisis ekonomi 2008, keadaan ekonomi memunculkan bentuk-bentuk hipermaskulinitas lainnya sebagai sarana untuk merebut kembali kekuatan dan identitas maskulin (Reddock dkk. 2009).

Dengan demikian, ide utama dalam studi ini adalah bahwa krisis ekonomi akibat Covid-19 ini menimbulkan fenomena sosial yang tergenderkan (gendered) berdasarkan 2 poin. Pertama, krisis muncul dari aktifitas ekonomi yang biasanya aspek keuangan tidak didistribusikan secara adil dan tidak mampu memenuhi hak-hak perempuan, baik sebagai pekerja / buruh pada umumnya atau sebagai pekerja rumah tangga (Elson 2010). Dalam sebuah study, tercatat bahwa secara global perempuan hampir tidak begitu terlibat dalam sektor pemerintahan dan pengambilan keputusan di sektor keuangan (Schuberth dan Young 2011). Padahal keterwakilan perempuan yang lebih baik dalam tata kelola keuangan publik dan swasta juga berpotensi membantu memberikan pandangan yang lebih beragam.

Kedua, krisis juga memiliki dampak pada permasalahan gender. Sifat gender dari krisis semacam ini dapat dipahami dalam penjelasan singkat berikut. Dalam ekonomi, kita mengenal proses produksi yang didalamnya melibatkan tenaga kerja, baik laki-laki maupun perempuan. Ketika krisis terjadi dan mobilitas manusia dibatasi, proses produksi ini akan terganggu. Ketika proses ini terganggu, implikasinya dapat berupa terhambatnya pertumbuhan anak, malnutrisi (terutama di antara perempuan yang mengorbankan asupan 
gizinya sendiri untuk memberi makan keluarganya), retaknya hubungan keluarga, dan peningkatan kekerasan antarpribadi. Ini adalah konsekuensi luas bagi perkembangan manusia. Memahami logika ini, kita bisa mengasumsikan bagaimana dampak krisis telah menjalar ke bidang keuangan (khususnya proses produksi) lalu berdampak pada kehidupan laki-laki dan perempuan.

Sudut pandang gender seperti ini sering diabaikan dalam pembahasan gender pada umumnya. Mengambil pendekatan gender juga dapat menghadirkan serangkaian solusi kebijakan yang luas terutama untuk perubahan struktural jangka panjang yang diperlukan untuk menghindari krisis serupa di masa depan.

\section{HASIL DAN PEMBAHASAN}

Kita telah mengetahui bagaimana pandemi ini muncul dari Cina dan kemudian menyebar ke berbagai penjuru dunia. Tulisan ini tidak akan terlalu detail membahas kronologi kemunculan Covid-19 tersebut karena telah banyak berita, laporan, maupun studi terkait. Sebagaimana telah disinggung, tulisan ini lebih fokus pada aspek krisis ekonomi dan kaitannya dengan masalah gender secara global yang akan dijelaskan pada bagian berikutnya. Pandemi Covid-19 adalah pandemi yang disebabkan oleh severe acute respiratory syndrome coronavirus 2 (SARS-CoV-2). Wabah tersebut diidentifikasi di Wuhan, Cina, pada Desember 2019, dan dinyatakan sebagai darurat kesehatan yang telah menjadi perhatian global. Pada 11 Maret 2020, wabah ini dinyatakan sebagai pandemi oleh World Health Organisation (WHO 2020). Pandemi tersebut telah menyebabkan gangguan ekonomi yang parah, penundaan dan pembatalan event olahraga, agama, politik dan budaya, serta kekurangan pasokan yang meluas karena adanya panic buying (Scipioni 2020). Di hampir semua negara, sekolah dan perguruan tinggi telah ditutup. Hal ini mempengaruhi kegiatan edukasi di banyak negara. Pemerintah di berbagai negara juga telah membatasi semua perjalanan yang tidak penting ke dan dari negara dan daerah yang menjadi epicentre. Namun, virus tersebut sudah menyebar di masyarakat di sebagian besar dunia dan banyak yang tidak tahu di mana atau bagaimana mereka terinfeksi.

Pandemi Covid-19 memiliki konsekuensi yang luas lebih dari sekedar masalah kesehatan. Ketika pandemi telah menyebar ke seluruh dunia, kekhawatiran telah bergeser ke penurunan bisnis di sektor jasa. Pandemi dianggap sebagai faktor utama penyebab resesi dan telah mempengaruhi hampir setiap industri besar secara negatif. Pademi ini juga merupakan salah satu penyebab utama jatuhnya pasar saham dan telah mengakibatkan pembatasan kebebasan dan pergerakan sosial (Williams 2020). 
Kebijakan dan himbauan oleh pemerintah untuk tetap tinggal di rumah memang telah memengaruhi banyak aktifitas bisnis. Namun menurut sebuah studi, pembatasan aktivitas yang diberlakukan oleh pemerintah hanya berdampak pada penurunan 7\% aktivitas ekonomi. Sebagian besar penurunan ekonomi justru disebabkan oleh individu yang secara suka rela membatasi diri dari aktifitas perdagangan (Goolsbee dan Syverson 2021). Pandemi Covid-19 telah menyebabkan setengah dari populasi dunia terhambat mobilitasnya karena kebijakan lockdown untuk menghentikan penyebaran virus (McFall-Johnsen, Kaplan, dan Frias 2020). Hal ini telah menyebabkan dampak yang parah bagi ekonomi di seluruh dunia, yang sebelumnya selama 2019 telah mengalami perlambatan ekonomi global yang menyebabkan stagnasi pasar saham dan aktivitas konsumen di seluruh dunia (The Guardian 2019).

Dengan adanya stagnasi aktifitas ekonomi tersebut, peningkatan pengangguran menjadi sangat tinggi di banyak negara. Organisasi Buruh International memperhitungkan bahwa pengangguran global telah menghilangkan 6,7 persen jam kerja secara global pada kuartal kedua tahun 2020 - setara dengan 195 juta pekerja penuh waktu (ILO 2020). Di beberapa negara, pengangguran diperkirakan mencapai sekitar 10\%, dengan negara-negara yang terkena dampak lebih parah dari pandemi Covid-19 memiliki tingkat pengangguran yang lebih tinggi (ABC News 2020). Negara-negara berkembang juga dipengaruhi oleh penurunan pengiriman uang dari luar negeri yang kemudian memperburuk krisis pangan global (CNN 2020).

Krisis ini juga menyebabkan penurunan harga minyak dunia, runtuhnya pariwisata, industri perhotelan, dan industri energi. Selain itu, krisis juga menyebabkan penurunan yang signifikan dalam aktivitas konsumen dibandingkan dengan dekade sebelumnya (Dan 2020). Pasar saham global jatuh masing-masing sekitar 20 hingga 30\% selama akhir Februari dan Maret 2020. Dalam situasi seperti ini, pasar saham global mengalami perubahan yang belum pernah terjadi sebelumnya dan tidak stabil, terutama karena ketidakpastian yang ekstrim di pasar (Samuelson 2020; Williams 2020).

Sebelum krisis akibat pandemic Covid-19, 16,4 miliar jam dihabiskan untuk pekerjaan perawatan tidak berbayar (unpaid care works) setiap hari di seluruh dunia. Lebih dari dua pertiga jam itu dilakukan oleh perempuan (Oxfam 2019). Sementara itu, pandemi telah memberikan guncangan yang signifikan terhadap ekonomi global, menimbulkan resesi di banyak negara dan kerugian yang sangat besar pada jutaan kehidupan dan mata pencaharian masyarakat.

Secara lebih khusus, pandemi Covid-19 telah memperburuk ketidaksetaraan gender yang ada dan menjadi ancaman serius bagi pencapaian kesetaraan gender. Pandemi telah 
menyebabkan peningkatan pengangguran, lebih banyak pekerjaan tidak dibayar (unpaidworks), dan tingkat kekerasan dalam rumah tangga serta putus sekolah yang belum pernah terjadi sebelumnya. Data dari UN Women menunjukkan bahwa ada 243 juta wanita umur 15-49 yang mengalami kekerasan fisik di masa pandemi tahun 2020 lalu (UN Women 2020d). Pandemi memiliki dampak yang sangat kuat pada perempuan yang, sebelum Covid-19, memiliki pekerjaan yang tidak aman dan hidup dekat dengan garis kemiskinan (UN Women 2020a). Pandemi diprediksi dapat mendorong 47 juta perempuan ke bawah garis kemiskinan (UN Women 2020b).

Di beberapa sektor, perempuan mengalami kehilangan pekerjaan yang tidak proporsional dan ketidakamanan ekonomi akibat pandemi. Sementara perempuan mencapai 39 persen dari pekerjaan global, mereka menyumbang 54\% dari keseluruhan kehilangan pekerjaan karena krisis. Tingkat kehilangan pekerjaan perempuan akibat Covid-19 sekitar 1,8 kali lebih tinggi daripada laki-laki secara global (McKinsey \& Company 2020). Di AS, misalnya, hampir 60 persen orang yang kehilangan pekerjaan karena pandemi virus corona adalah perempuan (Perrett 2020).

Kesenjangan gender dalam akses keuangan telah menciptakan tantangan tambahan bagi perempuan pengusaha untuk menemukan solusi modal kerja guna menghadapi guncangan likuiditas selama krisis. Di India, misalnya, 35 persen perempuan pengusaha melaporkan bahwa mereka mengalami penurunan pendapatan akibat Covid-19 (Chawla, Sahni, dan Sadhwani 2020). Di Sri Lanka, 72 persen perempuan pemilik usaha kecil melaporkan mengalami kesulitan mengakses layanan keuangan, dan 31 persen meminjam dari keluarga atau teman untuk mendukung bisnis mereka karena Covid-19 (IFC 2020). Hal ini barangkali memang tidak bisa merepresentasikan kasus serupa di negara-negara lain. Namun aspek utama yang perlu ditekankan adalah bahwa perempuan secara ekonomi telah terdampak Covid-19. Hal ini terjadi diberbagai negara, meski dengan presentasi yang berbeda-beda.

Sementara perempuan di sektor non-esensial telah mengalami kehilangan pekerjaan yang tidak proporsional. Banyak perempuan yang bekerja sebagai tenaga kesehatan, relawan, dan karyawan di industri makanan, ritel, kebersihan dan sanitasi terus memberikan kontribusi penting untuk memenuhi kebutuhan. Padahal, mereka rentan terhadap risiko kesehatan dan maupun resiko kesejahteraan mereka sendiri (UN Women 2020a).

Dengan penutupan sekolah dan fasilitas perawatan, perempuan di seluruh dunia mengambil tanggung jawab perawatan tambahan. Ketergantungan masyarakat pada 
perempuan dan anak perempuan dalam struktur perawatan informal dan formal semakin meningkat (UN Women 2020a). Sejumlah perempuan yang terkena dampak negatif dari pandemi harus dibayangi oleh kekhawatiran penutupan pekerjaan. Seruan untuk menjaga jarak secara fisik dan isolasi diri di rumah justru mendorong peningkatan risiko kekerasan dan pelecehan dalam rumah tangga (UN Women 2020c).

Krisis Covid-19 telah berdampak parah pada hampir 44 juta perempuan pekerja rumah tangga di seluruh dunia. Pandemi ini juga berdampak pada puluhan juta perempuan pedesaan miskin yang bergantung pada pertanian untuk mencari nafkah dan yang menghadapi pembatasan dalam mengakses ladang dan mempertahankan mata pencaharian mereka. Kebijakkan lockdowns yang masih diberlakukan di seluruh dunia juga telah berdampak buruk pada 740 juta perempuan yang bekerja di sektor informal di seluruh dunia (Care 2020).

Krisis keuangan jelas merugikan ekonomi dan masyarakat. Kehilangan pekerjaan dan kualitas hidup masyarakat menurun. Mereka dipaksa untuk memenuhi kebutuhan sehari-hari dengan sumber daya yang lebih sedikit yang mereka miliki. Ini bukan pertanda baik untuk pemulihan ekonomi atau kemajuan dalam mewujudkan hak-hak perempuan dan mencapai kesetaraan gender yang substantif.

Bagi sebagian orang, kebijakan pembatasan sosial terkait Covid-19 telah menyebabkan penutupan bisnis kecilnya yang seharusnya dapat mencukupi kebutuhan keluarganya. Bagi banyak kalangan, pandemi berarti berhenti bekerja dan tidak menerima tunjangan pengangguran atau tunjangan lainnya. Bagi perempuan yang tak terhitung jumlahnya di negara-negara dengan ekonomi yang tidak stabil, selain kehilangan pendapatan, beban perawatan yang tidak dibayar (unpaid care) dan pekerjaan rumah tangga meningkat secara dramatis (Power 2020, Seck 2021). Di saat semua orang menghadapi kesulitan yang belum pernah terjadi sebelumnya, perempuan menanggung beban dampak sosial ekonomi Covid-19 yang cukup mengkhawatirkan.

Perempuan miskin dan terpinggirkan bahkan lebih berisiko tertular Covid-19 dan meninggal karena penyakit tersebut, kehilangan mata pencaharian dan lebih banyak mengalami kekerasan (UN Women 2020b). Inilah cara Covid-19 merusak keuntungan ekonomi bagi perempuan dalam beberapa dekade terakhir. 
Figur 1. Prediksi jurang kemiskinan berdasarkan gender

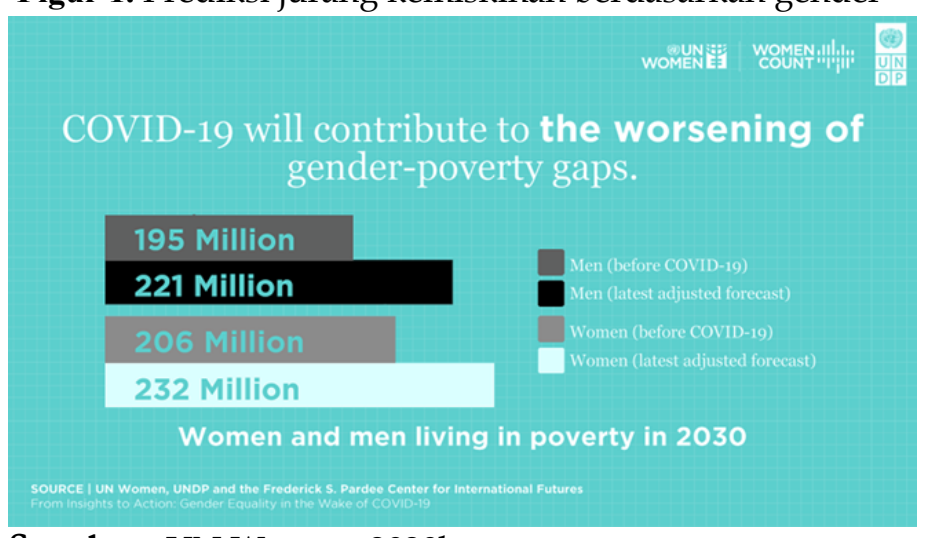

Sumber: UN Women, 2020b

Peningkatan kemiskinan akibat pandemi juga akan memperlebar jurang kemiskinan antar gender. Dengan kata lain, lebih banyak perempuan daripada pria yang akan jatuh ke dalam kemiskinan ekstrim. Hal ini terutama terjadi pada orang yang berusia 25 sampai 34 tahun, yaitu pada masa produktif dan masa pembentukan keluarga. Pada tahun 2021 ini, diprediksi akan ada 118 perempuan berusia antara 25 dan 34 di dunia yang hidup dalam kemiskinan ekstrim untuk setiap 100 laki-laki pada kelompok usia yang sama. Indeks ini dapat meningkat menjadi 121 perempuan miskin di dunia pada tahun 2030 (Azcona, Bhatt, dan Kapto 2020).

Seperti terlihat pada Figur 1, peningkatan kemiskinan yang ekstrem sebagai akibat dari pandemi dapat berarti gentingnya keamanan ekonomi perempuan. Hal ini terjadi karena perempuan cenderung mendapatkan upah lebih rendah dan memiliki pekerjaan yang kurang aman dibandingkan laki-laki. Sebagai akibat dari kemerosotan aktivitas ekonomi, perempuan secara khusus terkena PHK dan kehilangan mata pencaharian. Pandemi dan kebijakankebijakaan untuk mencegah penyebarannya menyebabkan peningkatan pengangguran yang tidak proporsional bagi perempuan (dibandingkan laki-laki), serta mengurangi jumlah jam kerja mereka.

Di Sebagian belahan dunia, pandemi Covid-19 juga memiliki dampak negatif yang sangat nyata. Sejak dimulainya pandemi, di Eropa dan Asia Tengah misalnya, 25\% perempuan wiraswasta kehilangan pekerjaan dibandingkan dengan 21\% laki-laki. Tren ini diperkirakan akan terus berlanjut seiring dengan meningkatnya pengangguran. Menurut perkiraan ILO, sekitar 140 juta pekerjaan penuh waktu bisa hilang akibat Covid-19, dan 19\% perempuan lebih mungkin kehilangan pekerjaan daripada laki-laki (UN Women 2020b). 


\section{KESIMPULAN}

Pandemi memang menyebabkan dampak ekonomi yang negatif. Namun lebih dari itu, disaat bersamaan pandemi ini juga membawa dampak buruh pada permasalahan sosial, tertama berupa tantangan pada kesetaraan gender. Saat ini, ketidakamanan ekonomi bukan hanya tentang pekerjaan dan hilangnya pendapatan. Masalah seperti ini memiliki efek negatif pada kehidupan perempuan selama bertahun-tahun. Dampak pada pendidikan dan pekerjaan memiliki konsekuensi jangka panjang yang, jika tidak ditangani, akan menghambat upaya kesetaraan gender yang sudah dicapai dengan susah payah.

Kesenjangan gender dapat menjadi semakin dalam bagi perempuan, termasuk penurunan yang signifikan dalam jumlah uang yang mereka peroleh. Ketidakamanan ekonomi juga meningkatkan risiko kekerasan berbasis gender. Tanpa sumber daya keuangan yang memadai, perempuan tidak dapat melepaskan diri dari pasangan yang melakukan kekerasan dan lebih berisiko menjadi korban eksploitasi seksual dan perdagangan manusia.

Konsekuensi ini tidak akan mudah hilang setelah pandemi berakhir. Konsekuensinya akan sangat mengerikan terutama bagi perempuan yang paling rentan seperti pekerja migran, pengungsi, kelompok etnis dan ras yang terpinggirkan, single parents, perempuan muda dan orang-orang miskin di dunia. Mereka yang baru-baru ini keluar dari kemiskinan ekstrem cenderung akan dapat tergelincir kembali ke dalamnya.

Tentunya, pemerintah perlu membuat kebijakan khusus untuk mengakomodir permasalahan kesenjangan semacam ini. Namun, tulisan ini tidak dimaksudkan untuk memberikan solusi terkait mengingat ada banyak kajian yang telah memberikan berbagai rekomendasi. Lebih dari itu, penting bagi kita, terutama pemerintah, untuk menekankan pentingnya pendataan yang mendukung. Sebagian besar negara tidak begitu menekankan pedataan atas isu terkait yang dipilah berdasarkan jenis kelamin, usia, dan karakteristik lainnya seperti kelas, ras, lokasi geografis, disabilitas, dan status migran. Kekurangan data yang besar ini (terutama di negara berkembang) membuat sangat sulit untuk memprediksi dampak jangka panjang pandemi. Negara-negara juga perlu mempertimbangkan kebijakan yang memprioritas perempuan yang, dalam tulisan ini, dianggap paling rentan. 


\section{DAFTAR PUSTAKA}

ABC News. 2020. "Unemployment Forecast to Soar to Highest Rate in Almost 30 Years." Diambil 16 Maret 2021 (https://www.abc.net.au/news/2020-04-13/coronavirusunemployment-Covid-19-treasury-figures-jobless-rate/12145542).

Ausín, Berta, Clara González-Sanguino, Miguel Ángel Castellanos, dan Manuel Muñoz. 2021. "Gender-Related Differences in the Psychological Impact of Confinement as a Consequence of Covid-19 in Spain.” Journal of Gender Studies 30(1):29-38. doi: 10.1080/09589236.2020.1799768.

Azcona, Ginette, Antra Bhatt, dan Serge Kapto. 2020. "The Covid-19 Boomerang Effect: New Forecasts Predict Sharp Increases in Female Poverty.” UN Women. Diambil 27 Maret 2021 (https:/ / data.unwomen.org/features/Covid-19-boomerang-effectnew-forecasts-predict-sharp-increases-female-poverty).

Care. 2020. "New Study: Covid-19 condemns millions of women to poverty, when they could be a solution to prosperity." Care International. Diambil 6 Maret 2021 (https://www.care-international.org/news/press-releases/new-study-Covid-19condemns-millions-of-women-to-poverty-when-they-could-be-a-solution-toprosperity).

Carlson, Daniel L., Richard Petts, dan Joanna R. Pepin. 2020. Changes in Parents' Domestic Labor During the Covid-19 Pandemic. preprint. SocArXiv.

Chawla, Megha, Prapti Sahni, dan Kamayani Sadhwani. 2020. "Can Covid-19 Be the Turning Point for Women Entrepreneurs in India?” Bain. Diambil 16 Februari 2021 (https://www.bain.com/insights/can-Covid-19-be-the-turning-point-forwomen-entrepreneurs-in-india/).

CNN. 2020. "Global famines of 'biblical proportions' will be caused by coronavirus pandemic, UN warns.” Diambil 16 Maret 2021 (https://edition.cnn.com/2020/04/22/africa/coronavirus-famine-un-warningintl/index.html).

Collins, Caitlyn, Liana Christin Landivar, Leah Ruppanner, dan William J. Scarborough. 2021. "COVID-19 and the Gender Gap in Work Hours." Gender, Work \& Organization 28(S1):101-12. doi: 10.1111/gwao.12506.

Coskun, Sena, dan Husnu Dalgic. 2020. The Emergence of Procyclical Fertility: The Role of Gender Differences in Employment Risk. University of Bonn and University of Mannheim, Germany.

Cousins, Sophie. 2020. “Covid-19 Has 'Devastating' Effect on Women and Girls.” The Lancet 396(10247):301-2. doi: 10.1016/S0140-6736(20)31679-2.

Dan, Avi. 2020. "Consumer Attitudes And Behavior Will Change In The Recession, And Persist When It Ends.” Forbes. Diambil 16 Maret 2021 
(https://www.forbes.com/sites/avidan/2020/04/13/consumer-attitudes-andbehavior-will-change-in-the-recession-and-persist-when-it-ends/).

Doepke, Matthias, dan Michèle Tertilt. 2016. "Families in macroeconomics.” Hlm. 1789_ 1891 dalam Handbook of macroeconomics. Vol. 2. Elsevier.

Elson, Diane. 2010. "Gender and the global economic crisis in developing countries: a framework for analysis.” Gender \& Development 18(2):201-12.

Gaetano, Chris. 2020. “IMF Says 'Great Lockdown' Worst Recession Since Depression, Far Worse Than Last Crisis.” Diambil 16 Maret 2021 (https://www.nysscpa.org/news/publications/the-trustedprofessional/article/imf-says- $\% 27$ great-lockdown $\% 27$-worst-recession-sincedepression-far-worse-than-last-crisis-041420).

Goolsbee, Austan, dan Chad Syverson. 2021. "Fear, Lockdown, and Diversion: Comparing Drivers of Pandemic Economic Decline 2020.” Journal of Public Economics 193:104311. doi: 10.1016/j.jpubeco.2020.104311.

Hafi, Bishurul, dan Na Uvais. 2020. "Difficulties Faced by Sexual and Gender Minorities during COVID-19 Crisis.” Psychiatry and Clinical Neurosciences 74(8):444-444. doi: $10.1111 /$ pen.13080.

Horesh, Danny, Rony Kapel Lev-Ari, dan Ilanit Hasson-Ohayon. 2020. "Risk Factors for Psychological Distress during the COVID-19 Pandemic in Israel: Loneliness, Age, Gender, and Health Status Play an Important Role.” British Journal of Health Psychology 25(4):925-33. doi: 10.1111/bjhp.12455.

IFC. 2020. "Gendered Impacts of Covid-19 on Small and Medium-Sized Enterprises in Sri Lanka." IFC. Diambil 16 Maret 2021 (https://www.ifc.org/wps/wcm/connect/REGION_EXT_Content/IFC_Extern al_Corporate_Site/South+Asia/Resources/Gendered+Impacts+of+COVID19+o $\mathrm{n}+$ Small+and + Medium + Sized + Enterprises + in + Sri+Lanka).

ILO. 2020. "Covid-19 Causes Devastating Losses in Working Hours and Employment." Diambil 13 Maret 2021 (http://www.ilo.org/global/about-theilo/newsroom/news/WCMS_740893/lang--en/index.htm).

IMF. 2020. "World Economic Outlook Update, June 2020: A Crisis Like No Other, An Uncertain Recovery.” IMF. Diambil 11 Maret 2021 (https://www.imf.org/en/Publications/WEO/Issues/2020/06/24/WEOUpdateJ une2020).

Jin, Jian-Min, Peng Bai, Wei He, Fei Wu, Xiao-Fang Liu, De-Min Han, Shi Liu, dan Jin-Kui Yang. 2020. "Gender Differences in Patients With Covid-19: Focus on Severity and Mortality.” Frontiers in Public Health 8:152. doi: 10.3389/fpubh.2020.00152. 
Knowles, James, Ernesto Pernia, dan Mary Racelis. 1999. "Social consequences of the financial crisis in Asia."

McFall-Johnsen, Morgan, Juliana Kaplan, dan Lauren Frias. 2020. "Our Ongoing List of How Countries Are Reopening, and Which Ones Remain under Lockdown.” Business Insider Australia. Diambil 10 Maret 2021 (https://www.businessinsider.com.au/countries-on-lockdown-coronavirus-italy2020-3).

McKinsey \& Company. 2020. "Covid-19 and Gender Equality: Countering the Regressive Effects.” McKinsey \& Company. Diambil 13 Maret 2021 (http://ceros.mckinsey.com/coronavirus-promo-video-desktop).

Oxfam. 2019. "Care Work Feminist Scorecard.” Oxfam Canada. Diambil 16 Maret 2021 (https://www.oxfam.ca/feminist-policy-scorecard-2019/care-work/).

Perrett, Connor. 2020. "Nearly $60 \%$ of people who have lost their jobs due to the coronavirus pandemic are women, according to report." Business Insider. Diambil 16 Maret 2021 (https://www.businessinsider.com/coronavirus-unemploymentwomen-60-percent-2020-4).

Power, K., 2020. The COVID-19 pandemic has increased the care burden of women and families. Sustainability: Science, Practice and Policy, 16(1), pp.67-73.

Reddock, Rhoda, Elsa Goveia, M. G. Smith, Lloyd Best, dan W. G. Demas. 2009. "What now for Caribbean people and their leaders? Reflections on the current economic and social crisis: A gender perspective."

Rocha, Mercedes González de la. 1988. "Economic Crisis, Domestic Reorganisation and Women's Work in Guadalajara, Mexico.” Bulletin of Latin American Research 7(2):207-23. doi: 10.2307/3338289.

Samuelson, Robert J. 2020. “Opinion | What the Crash of 2020 Means.” Washington Post, Maret 12.

Schuberth, Helene, dan Brigitte Young. 2011. "The role of gender in governance of the financial sector." Questioning financial governance from a feminist perspective 9:132.

Scipioni, Jade. 2020. "Why There Will Soon Be Tons of Toilet Paper, and What Food May Be Scarce, According to Supply Chain Experts.” CNBC. Diambil 1 Maret 2021 (https://www.cnbc.com/2020/03/18/supply-chain-experts-foods-that-could-beless-available-in-pandemic.html).

Seck, P.A., Encarnacion, J.O., Tinonin, C. and Duerto-Valero, S., 2021. Gendered Impacts of COVID-19 in Asia and the Pacific: Early Evidence on Deepening Socioeconomic Inequalities in Paid and Unpaid Work. Feminist Economics, 27(1-2), pp.117-132. 
The Guardian. 2019. "Nations Must Unite to Halt Global Economic Slowdown, Says New IMF Head." The Guardian. Diambil 16 Maret 2021 (http://www.theguardian.com/business/2019/oct/08/nations-must-unite-haltglobal-economic-slowdown-new-imf-head-kristalina-georgieva).

The Guardian, Larry. 2020. “'Great Lockdown' to Rival Great Depression with 3\% Hit to Global Economy, Says IMF." The Guardian. Diambil 16 Januari 2021 (http://www.theguardian.com/business/2020/apr/14/great-lockdowncoronavirus-to-rival-great-depression-with-3-hit-to-global-economy-says-imf).

UN Women. 2020a. "Empower Women - Covid-19 and Gender Equality: A Call to Action for the Private Sector." EmpowerWomen. Diambil 16 Maret 2021 (https://www.empowerwomen.org/en/resources/documents/2020/04/Covid-19and-gender-equality-a-call-to-action-for-the-private-sector?lang=en).

UN Women. 2020b. From Insights to Action: Gender Equality in the Wake of Covid-19. UN Women.

UN Women. 2020c. "The Covid-19 Shadow Pandemic: Domestic Violence in the World of Work - A Call to Action for the Private Sector | WEPs.” Diambil 16 Maret 2021 (https://www.weps.org/resource/Covid-19-shadow-pandemic-domestic-violenceworld-work-call-action-private-sector).

UN Women. 2020d. The impact of COVID-19 on women. United Nations entity for gender equality and the empowerment of women (UN Women). United Nations Secretariat. Diambil 29 April 2021 (https:/ /www. unwomen. org//media/headquarters/attachments/sections/library/publications/2020/policybrief-the-impact-of-COVID-19-on-women-en. Pdf).

WHO. 2020. “WHO Director-General's Opening Remarks at the Media Briefing on Covid-19 - 11 March 2020.” World Health Organization. Diambil 16 Maret 2021 (https://www.who.int/director-general/speeches/detail/who-director-general-sopening-remarks-at-the-media-briefing-on-Covid-19---11-march-2020).

Williams, Sean. 2020. "Stock Market Crash 2020: Everything You Need to Know." The Motley Fool. Diambil 16 Maret 2021 (https:/ /www.fool.com/investing/2020/03/10/stock-market-crash-2020everything-you-need-to-kno.aspx). 